\title{
$\beta$-Adrenergic Receptor Activation Facilitates Induction of a Protein Synthesis-Dependent Late Phase of Long-Term Potentiation
}

\author{
Jennifer N. Gelinas ${ }^{1}$ and Peter V. Nguyen ${ }^{1,2,3}$ \\ Departments of ${ }^{1}$ Physiology and ${ }^{2}$ Psychiatry and ${ }^{3}$ Centre for Neuroscience, University of Alberta School of Medicine, Edmonton, Alberta, Canada T6G 2H7
}

\begin{abstract}
Long-term potentiation (LTP) is activity-dependent enhancement of synaptic strength that can critically regulate long-term memory storage. Like memory, LTP exhibits at least two mechanistically distinct temporal phases. Early LTP (E-LTP) does not require protein synthesis, whereas the late phase of LTP (L-LTP), like long-term memory, requires protein synthesis. Hippocampal $\beta$-adrenergic receptors can regulate expression of both E-LTP and long-term memory. Although $\beta$-adrenergic receptor activation enhances the ability of subthreshold stimuli to induce E-LTP, it is unclear whether such activation can facilitate induction of L-LTP. Here, we use electrophysiological recording methods on mouse hippocampal slices to show that when synaptic stimulation that is subthreshold for inducing L-LTP is paired with $\beta$-adrenergic receptor activation, the resulting LTP persists for over $6 \mathrm{~h}$ in area CA1. Like L-LTP induced by multiple trains of high-frequency electrical stimulation, this LTP requires protein synthesis. Unlike tetanus-induced L-LTP, however, L-LTP induced by $\beta$-adrenergic receptor activation during subthreshold stimulation appears to involve dendritic protein synthesis but not somatic transcription. Maintenance of this LTP also requires activation of extracellular signal-regulated kinases (ERKs). Thus, $\beta$-adrenergic receptor activation elicits a type of L-LTP that requires translation and ERK activation but not transcription. This form of L-LTP may be a cellular mechanism for facilitation of behavioral long-term memory during periods of heightened emotional arousal that engage the noradrenergic modulatory system.
\end{abstract}

Key words: noradrenergic receptors; LTP; hippocampus; protein synthesis; memory; neuromodulation

\section{Introduction}

Enhancement of hippocampal synaptic strength ["long-term potentiation" (LTP)] can critically regulate storage of information in the mammalian brain (Bliss and Collingridge, 1993; Moser et al., 1998; Martin et al., 2000; Brun et al., 2001; Nathe and Frank, 2003). Like behavioral memory, LTP exhibits at least two mechanistically distinct temporal phases (Davis and Squire, 1984; Krug et al., 1984). Early LTP (E-LTP) does not require new protein synthesis, whereas the late phase of LTP (L-LTP), like longterm memory, requires macromolecular synthesis (Davis and Squire, 1984; Stanton and Sarvey, 1984; Deadwyler et al., 1987; for review, see Huang et al., 1996; Kandel, 2001). Some forms of L-LTP also require transcription (Nguyen et al., 1994). There is strong correlative evidence that L-LTP contributes to hippocampal consolidation of long-term memory (Doyere and Laroche, 1992; Bourtchouladze et al., 1994; Abel et al., 1997; Jones et al., 2001; Genoux et al., 2002).

The ability of neuromodulatory transmitters to modify syn-

Received 0ct. 7, 2004; revised Feb. 7, 2005; accepted Feb. 11, 2005.

This work was supported by the Canadian Institutes of Health Research (CIHR) and the Canadian Neurotrauma Research Program. J.N.G. was supported by a CIHR MD-PhD Studentship. P.V.N. received a Faculty Senior Scholarship from the Alberta Heritage Foundation for Medical Research.

Correspondence should be addressed to Dr. P. V. Nguyen, Department of Physiology, University of Alberta, Medical Sciences Building, Edmonton, Alberta, Canada T6G 2H7. E-mail: peter.nguyen@ualberta.ca. D0I:10.1523/JNEUROSCI.4175-04.2005

Copyright $\odot 2005$ Society for Neuroscience $\quad$ 0270-6474/05/253294-10\$15.00/0 aptic plasticity thresholds constitutes a form of activitydependent "metaplasticity" (Abraham and Bear, 1996). One neuromodulator that is prominent in the hippocampus is noradrenaline. The hippocampus receives abundant innervation from noradrenergic afferents (Loy et al., 1980). Activation of $\beta$-adrenergic receptors is involved in enhancement of memory after emotional experiences (McGaugh, 1989; Cahill et al., 1994). Hippocampal $\beta$-adrenergic receptor activation can also initiate signaling pathways known to be critical for LTP (Segal, 1982; Stanton and Sarvey, 1985; Madison and Nicoll, 1986). Application of $\beta$-adrenergic receptor agonists induces long-lasting changes in synaptic strength in the perforant pathway (Dahl and Sarvey, 1989) and also enhances LTP in the mossy fiber pathway (Hopkins and Johnston, 1984, 1988; Huang and Kandel, 1996). At Schaeffer collateral-commissural CA1 synapses, $\beta$-adrenergic receptor activation alone is insufficient to elicit LTP, but it does enhance the effectiveness of subthreshold stimuli for inducing LTP (Thomas et al., 1996; Katsuki et al., 1997). Specifically, lowfrequency stimulation (LFS) of Schaeffer collaterals in area CA1 of mouse hippocampal slices elicits robust E-LTP when applied in the presence of isoproterenol (ISO), a $\beta$-adrenergic receptor agonist (Thomas et al., 1996). In the absence of ISO, the same stimulation elicits no persistent change in basal synaptic strength (Thomas et al., 1996). Thus, activation of $\beta$-adrenergic receptors lowers the threshold for induction of E-LTP (Hopkins and Johnston, 1988; Thomas et al., 1996; Katsuki et al., 1997). Puta- 
tive mechanisms regulating this induction effect include the cAMP/protein kinase A (PKA) system and the mitogen-activated protein kinase (MAPK) cascade (Raman et al., 1996; Winder et al., 1999). Specifically, it is unclear whether, and how, induction and stabilization of CA1 L-LTP are regulated by $\beta$-adrenergic receptors.

Does $\beta$-adrenergic receptor stimulation facilitate the induction and stabilization of L-LTP by subthreshold stimuli? If so, does this form of L-LTP require transcription and translation? We show here that activating $\beta$-adrenergic receptors during subthreshold electrical stimulation enhances induction and stabilization of L-LTP. This L-LTP requires protein synthesis but not transcription. Thus, our findings show that $\beta$-adrenergic receptors control metaplasticity of L-LTP by engaging local protein synthesis.

\section{Materials and Methods}

Animals. Female C57BL/6 mice, 8-12 weeks of age (Charles River, Montreal, Quebec, Canada) were used for all experiments. Animals were housed at the University of Alberta using guidelines approved by the Canadian Council on Animal Care.

Electrophysiology. After cervical dislocation and decapitation, transverse hippocampal slices ( $400 \mu \mathrm{m}$ thickness) were prepared as described by Nguyen and Kandel (1997). Slices were maintained in an interface chamber at $28^{\circ} \mathrm{C}$ and perfused (1-2 $\mathrm{ml} / \mathrm{min}$ ) with artificial CSF (ACSF) composed of the following (in $\mathrm{mM}$ ): $124 \mathrm{NaCl}, 4.4 \mathrm{KCl}, 1.3 \mathrm{MgSO}_{4}, 1.0$ $\mathrm{NaH}_{2} \mathrm{PO}_{4}, 26.2 \mathrm{NaHCO}_{3}, 2.5 \mathrm{CaCl}_{2}$, and 10 glucose, aerated with $95 \%$ $\mathrm{O}_{2}$ and $5 \% \mathrm{CO}_{2}$. Extracellular field EPSPs (fEPSPs) were recorded with a glass microelectrode filled with ACSF (resistances, 2-3 M 2 ) and positioned in the stratum radiatum of area CA1. fEPSPs were obtained by stimulating the Schaeffer collateral-commissural fibers with a bipolar nickel-chromium electrode (130 $\mu \mathrm{m}$ diameter). Stimulation intensity (0.08 ms pulse duration) was adjusted to evoke fEPSP amplitudes that were $40 \%$ of maximal size (Schimanski et al., 2002; Woo and Nguyen, 2003). Subsequent fEPSPs were elicited at the rate of once per minute at this "test" stimulation intensity.

A second independent pathway within the stratum radiatum was monitored during some experiments by placing a second bipolar stimulating electrode in this region. The absence of paired-pulse facilitation, when electrodes were activated by paired S1-S2 stimuli $75 \mathrm{~ms}$ apart, was used as the criterion to determine stimulation of independent pathways. For experiments on isolated CA1 dendrites, hippocampal slices were cut in ice-cold ACSF and perfused in an interface chamber for $1 \mathrm{~h}$. Two incisions were then made under a dissecting microscope. One cut was applied in the stratum radiatum, adjacent to the cell body layer of area CA1, and another incision was created in area CA3 (Woo and Nguyen, 2003). Subsequently, slices were allowed to recover for an additional hour in the interface chamber before recording commenced. The following criteria were used to assess successful isolation of CA1 dendrites from CA1 pyramidal somata (Woo and Nguyen, 2003): (1) absence of a population spike when the recording electrode was placed at the cell body layer and strong stimulation was applied in the stratum radiatum below the cut; and (2) absence of a fEPSP in the stratum radiatum below the incision when stimulation was applied at the basilar dendrites in the stratum oriens.

LTP was induced by applying one train of high-frequency stimulation (HFS; $100 \mathrm{~Hz}, 1 \mathrm{~s}$ duration at test strength). Depotentiation (DPT) was induced by applying LFS consisting of $5 \mathrm{~Hz}$ for $3 \mathrm{~min}$.

Drugs. The $\beta$-adrenergic receptor agonist ISO $[R(-)$ isoproterenol(+)-bitartrate, $1 \mu \mathrm{M}$; Sigma, St. Louis, MO] and the $\beta$-adrenergic receptor antagonist propranolol [( \pm )-propranolol hydrochloride, $50 \mu \mathrm{M}$; Research Biochemicals, Natick, MA] were prepared daily as concentrated stock solutions at 1 and $50 \mathrm{~mm}$, respectively, in distilled water. Two different inhibitors of protein synthesis, anisomycin (25 $\mu \mathrm{M}$; Sigma) and emetine (20 $\mu \mathrm{M}$; Sigma), were prepared as concentrated stock solutions at $25 \mathrm{~mm}$ in DMSO and $20 \mathrm{~mm}$ in distilled water, respectively. Both anisomycin and emetine, at lower concentrations than those used here, blocked protein synthesis by $>80 \%$ in hippocampal slices (Stanton and Sarvey, 1984; Frey et al., 1988). The stock solution (25 $\mathrm{mm}$ ) of a transcriptional inhibitor, actinomycin D (ACT-D; $25 \mu \mathrm{M}$ bath concentration; Bioshop Canada, Burlington, Ontario, Canada), was prepared in DMSO. At the bath concentration used here, ACT-D has been shown to block transcription by $>70 \%$ in hippocampal slices (Nguyen et al., 1994). A $\mathrm{D}_{1} / \mathrm{D}_{5}$ antagonist, $R(+)$-7-chloro-8-hydroxy-3-methyl-1phenyl-2,3,4,5,-tetrahydro- $1 \mathrm{H}$-3-benzazepine (SCH 23390) (1 $\mu \mathrm{M}$; Sigma), was prepared as a $1 \mathrm{~mm}$ stock solution in water. A MAPK antagonist, 2-(2-amino-3-methoxyphenyl)-4H-1-benzopyran-4-one (PD 98059) ( $50 \mu \mathrm{M}$; Sigma), was prepared in DMSO at a concentration of 10 mM. Each drug was diluted in ACSF to the desired final concentration and then bath applied. The final concentration of DMSO did not affect either basal synaptic transmission or LTP (data not shown). ISO was applied for a total duration of $15 \mathrm{~min}$, starting $10 \mathrm{~min}$ before stimulation protocols. Propranolol and PD 98059 were applied $30 \mathrm{~min}$ before ISO application and were present during ISO application. Anisomycin, emetine, ACT-D, and SCH 23390 were applied 20 min before ISO application and were present throughout ISO application and $10 \mathrm{~min}$ after ISO application. All drug experiments were performed under dimmed light conditions because of the light sensitivity of drugs. Drug experiments were interleaved with drug-free controls.

Data analysis. The initial slope of the fEPSP was measured as an index of synaptic strength (Johnston and Wu, 1995). The average "baseline" slope values were acquired over a period of $20 \mathrm{~min}$ before experimental protocols were applied. fEPSP slopes were measured at $120 \mathrm{~min}$ after LFS or HFS for comparisons of L-LTP. Student's $t$ test was used for statistical comparisons of mean fEPSP slopes between two groups, with a significance level of $p<0.05$. One-way ANOVA and Tukey-Kramer post hoc tests were done for comparison of more than two groups to determine which groups were significantly different from the others. The Welch correction was applied in cases in which the SDs of groups being compared were significantly different. All values shown are means \pm SEM, with $n=$ number of slices.

\section{Results}

\section{$\boldsymbol{\beta}$-Adrenergic receptor activation facilitates expression of L-LTP}

Activation of $\beta$-adrenergic receptors in the CA1 region of mouse hippocampal slices has been shown to enhance induction of LTP by stimulation protocols that normally have no persistent effect on fEPSPs [for rat data in CA3 and CA1, see Hopkins and Johnston (1988)] (Thomas et al., 1996; Katsuki et al., 1997). We tested the idea that $\beta$-adrenergic receptor activation enhances expression of L-LTP. Application of a $\beta$-adrenergic receptor agonist, ISO $(1.0 \mu \mathrm{M})$, to hippocampal slices for $15 \mathrm{~min}$ induced a small enhancement of synaptic transmission in area CA1 that faded soon after drug washout (Fig. 1 A) (fEPSPs were 105.3 \pm $4.2 \%$ of baseline slopes $60 \mathrm{~min}$ after ISO application). Similarly, a $5 \mathrm{~Hz}$ stimulation for $3 \mathrm{~min}$ to the Schaeffer collateral-commissural fibers in CA1 elicited only a transient depression of synaptic transmission that quickly recovered to baseline levels (Fig. $1 B$ ) (fEPSPs were $101.4 \pm 3.5 \%$ of baseline 60 min after a $5 \mathrm{~Hz}$ stimulation). However, a $5 \mathrm{~Hz}$ stimulation delivered in the presence of ISO induced LTP that persisted for $>2 \mathrm{~h}$ (Fig. $1 \mathrm{~B}$ ) (fEPSPs were potentiated to $151.5 \pm 10.9 \% 120 \mathrm{~min}$ after a $5 \mathrm{~Hz}$ stimulation; $p<0.01$ compared with $5 \mathrm{~Hz}$ alone). Because E-LTP can decay within $2 \mathrm{~h}$ in these conditions (Huang and Kandel, 1994), these results suggest that pairing $\beta$-adrenergic receptor activation with $5 \mathrm{~Hz}$ LFS elicits stable L-LTP. To test the idea that facilitation of L-LTP expression by ISO depends on the induction protocol, we examined LTP generated by one train of $100 \mathrm{~Hz}$ stimulation (1 $s$ duration). This procedure induces E-LTP in mouse hippocampal slices (Duffy et al., 2001) (Fig. 1C) (fEPSPs were 102.3 $\pm 5.5 \%$ $120 \mathrm{~min}$ after $100 \mathrm{~Hz}$ ). When ISO was applied during the single train, the persistence of LTP was enhanced (Fig. 1C) (fEPSPs were 
potentiated to $155.4 \pm 14.1 \% 120 \mathrm{~min}$ after $100 \mathrm{~Hz} ; p<0.01$ compared with $1 \times 100 \mathrm{~Hz}$ alone). Thus, $\beta$-adrenergic receptor activation enhances the ability of stimuli to induce L-LTP. The combined data from both $5 \mathrm{~Hz}$ and $1 \times 100 \mathrm{~Hz}$ stimulation underscore the idea that the enhancement of persistence of LTP by $\beta$-adrenergic receptor activation is not restricted to particular stimulation protocols.

\section{LTP elicited by ISO application during subthreshold stimulation requires $\boldsymbol{\beta}$ - adrenergic receptors and MAPK but not dopamine receptors}

Induction of LTP by low-frequency electrical stimulation paired with ISO application was inhibited by a $\beta$-adrenergic antagonist, propranolol (Fig. 2A) (fEPSPs were $106.5 \pm 6.8 \%$ of baseline 60 min after a $5 \mathrm{~Hz}$ stimulation). This LTP therefore requires activation of $\beta$-adrenergic receptors. However, activation of dopamine $\mathrm{D}_{1} / \mathrm{D}_{5}$ receptors has also been shown to increase expression of early and late LTP in area CA1 (Huang and Kandel, 1995; Otmakhova and Lisman, 1996). To ascertain that our observed enhancement of LTP by ISO is not also mediated by dopamine receptors, we applied a $D_{1} / D_{5}$ receptor antagonist, SCH 23390. Induction and maintenance of LTP elicited by pairing ISO with a $5 \mathrm{~Hz}$ stimulation was not inhibited in the presence of SCH 23390 (Fig. 2B) (fEPSPs were potentiated to $158.8 \pm$ $11.6 \% 120 \mathrm{~min}$ after a $5 \mathrm{~Hz}$ stimulation; $p>0.5$ compared with ISO plus $5 \mathrm{~Hz}$ alone). These data show that ISO selectively activates $\beta$-adrenergic receptors to establish LTP.

Induction of LTP in the presence of ISO and a $5 \mathrm{~Hz}$ stimulation is dependent on the intracellular cAMP cascade (Raman et al., 1996; Winder et al., 1999). However, the signaling pathways involved in the facilitated maintenance of LTP by $\beta$-adrenergic receptor activation are unknown. As a preliminary step toward identifying these pathways, we examined the effects of a MAPK inhibitor, PD 98059, on our $\beta$-adrenergic-mediated L-LTP. Pairing $1 \times 100 \mathrm{~Hz}$ electrical stimulation with ISO application in the presence of PD 98059 inhibited L-LTP (Fig. 2C) (fEPSPs were $108.9 \pm 6.6 \% 120 \mathrm{~min}$ after $1 \times 100 \mathrm{~Hz} ; p<0.01$ compared with ISO plus $1 \times 100 \mathrm{~Hz}$ alone). Because LTP induced by $1 \times 100 \mathrm{~Hz}$ stimulation is independent of the MAPK cascade (Winder et al., 1999 ), our data suggest that $\beta$-adrenergic receptor activation recruits MAPKs to stabilize LTP.

\section{$\beta$-Adrenergic receptor activation paired with subthreshold stimulation renders L-LTP immune to DPT}

DPT is activity-induced reversal of LTP that can occur during a restricted time interval immediately after LTP induction (Barrionuevo et al., 1980; Staubli and Lynch, 1990; Fujii et al., 1991; Bashir and Collingridge, 1994; Huang et al., 1999). LFS, such as 5 Hz for 3 min, can elicit DPT (Staubli and Lynch, 1990; Fujii et al., 1991; O’Dell and Kandel, 1994). Furthermore, susceptibility to
B.

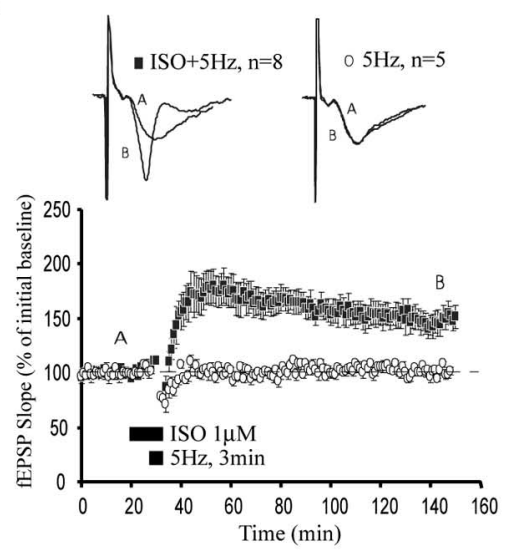

D.

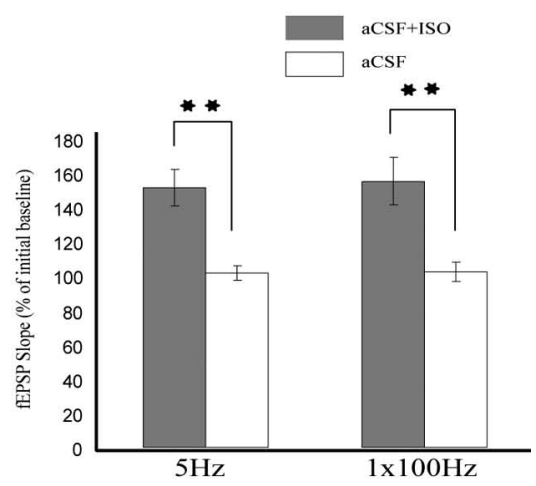

Figure 1. $\quad \beta$-Adrenergic receptor activation facilitates induction and enhances persistence of L-LTP. $\boldsymbol{A}$, ISO application alone has ( after commencement of baseline recording and $120 \mathrm{~min}$ after stimulation protocol. Calibration: $5 \mathrm{mV}, 2 \mathrm{~ms}$.

DPT has been shown to depend on molecular mechanisms associated with the maintenance of L-LTP (Barco et al., 2002; Woo and Nguyen, 2002, 2003). Processes involved in the cellular consolidation of E-LTP to L-LTP can also confer immunity to DPT (Woo and Nguyen, 2003).

Is L-LTP generated by pairing $\beta$-adrenergic receptor activation with LFS also immune to DPT? To address this question, we paired ISO application with $5 \mathrm{~Hz}$ LFS to induce L-LTP, allowed $10 \mathrm{~min}$ for ISO washout, and then administered LFS ( $5 \mathrm{~Hz}$ for 3 min) in an attempt to depotentiate the L-LTP. We found that L-LTP could not be persistently erased; fEPSPs recovered to preDPT, potentiated values (Fig. $3 A$ ) (fEPSPs were $140.8 \pm 11.2 \%$ and $143.9 \pm 9.0 \%$ before DPT and $120 \mathrm{~min}$ after DPT, respectively; $p>0.5$ ).

Next, we examined whether LTP induced by ISO application paired with one train of HFS was similarly immune to DPT. LFS applied $10 \mathrm{~min}$ after one train of HFS alone caused an immediate and persistent reversal of LTP (Fig. 3B) (fEPSPs were $133.0 \pm$ $8.0 \%$ and $101.0 \pm 4.4 \%$ before DPT and $120 \mathrm{~min}$ after DPT, respectively; $p<0.01$ ). However, application of ISO during one train of HFS alters the properties of the induced LTP. In this case, LTP did not persistently depotentiate, and it recovered to preDPT values (Fig. $3 B$ ) (fEPSPs were $158.1 \pm 12.6 \%$ and $155.5 \pm$ $10.4 \%$ before DPT and 120 min after DPT, respectively; $p>0.5$ ). 
A.

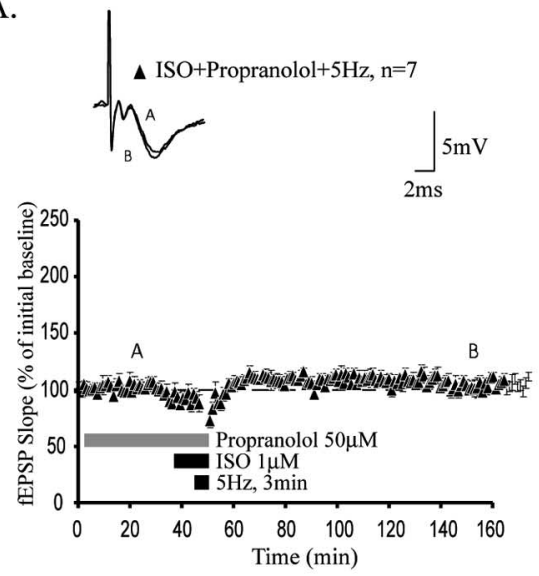

C.

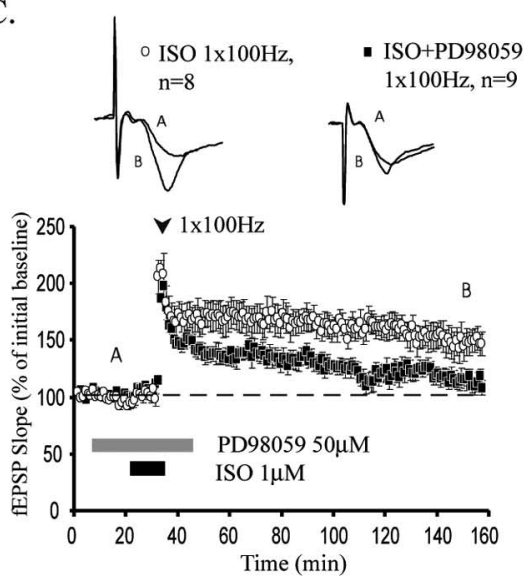

Figure 2. LTP elicited by ISO application during subthreshold stimulation requires $\beta$-adrenergic receptors and MAPK but not dopamine receptors. $A$, Application of propranolol inhibits LTP generated by pairing $5 \mathrm{~Hz}$ stimulation with ISO application (filled triangles). B. Application of SCH 23390 does not inhibit LTP generated by pairing $5 \mathrm{~Hz}$ stimulation with ISO application (filled squares). C, Application of PD 98059 inhibits the maintenance of LTP induced by pairing $1 \times 100 \mathrm{~Hz}$ stimulation with ISO application (filled squares). All sample traces were taken $10 \mathrm{~min}$ after commencement of baseline recording and $120 \mathrm{~min}$ after stimulation protocol. Calibration: $5 \mathrm{mV}, 2$ ms.

Because pairing ISO with LFS induces LTP, it was important to ensure that the ISO had been washed out before the LFS given for DPT. To test this assumption, we administered ISO for 15 $\mathrm{min}$, allowed $10 \mathrm{~min}$ for drug washout, then applied $5 \mathrm{~Hz}$ LFS to mimic the DPT stimulus. We found that in this situation, the LFS did not induce LTP (Fig. 3C) (fEPSPs were $104.7 \pm 5.8 \% 30 \mathrm{~min}$ after LFS). Therefore, a 10 min interval is sufficient to allow for drug washout, and DPT experiments were not confounded by interaction of the $5 \mathrm{~Hz}$ DPT stimulus with ISO. Activation of $\beta$-adrenergic receptors thus triggers pathways that not only facilitate induction and expression of L-LTP but make this L-LTP immune to persistent reversal by depotentiating stimuli.

Protein synthesis is required for L-LTP induced by

$\beta$-adrenergic receptor activation paired with subthreshold stimulation

De novo protein synthesis is a hallmark of L-LTP. Whereas E-LTP is protein synthesis independent, L-LTP requires protein synthesis for its maintenance (Stanton and Sarvey, 1984; Deadwyler et al., 1987; Frey et al., 1988; Nguyen and Kandel, 1996; for review, see Huang et al., 1996; Kandel, 2001). Furthermore, studies have shown that protein synthesis is required for synaptic immunity to DPT (Woo and Nguyen, 2003). We therefore investigated whether L-LTP generated by activating $\beta$-adrenergic receptors during $5 \mathrm{~Hz}$ LFS or $1 \times 100 \mathrm{~Hz}$ stimulation resembles previously characterized forms of L-LTP by requiring protein synthesis.

First, anisomycin, an inhibitor of translation, was bath applied at a concentration that inhibits $>80 \%$ of protein synthesis (Frey et al., 1988). L-LTP elicited by pairing $\beta$-adrenergic receptor activation with $5 \mathrm{~Hz}$ LFS decayed in the presence of anisomycin (Fig. 4A) (fEPSPs were $115.1 \pm 10.3 \% 120$ min after LFS). To exclude the possibility that the decay in LTP could be attributed to effects of anisomycin unrelated to protein synthesis, we repeated this experiment using another translational inhibitor, emetine. Bath application of emetine likewise inhibited L-LTP when ISO was administered during $5 \mathrm{~Hz}$ LFS (Fig. 4B) (fEPSPs were $107.6 \pm$ $8.9 \% 120$ min after LFS). An ANOVA that compared fEPSPs 120 min after conjoint ISO application and LFS in the presence of anisomycin, emetine, or no drug demonstrated significant differences between groups $\left(F_{(2,30)}=4.695 ; p<0.02\right)$. Subsequent Tukey-Kramer post hoc tests revealed that both anisomycin and emetine significantly inhibited L-LTP $(p<0.05)$. Furthermore, the anisomycin and emetine groups did not significantly differ from each other in their impairment of L-LTP $(p>0.05)$.

L-LTP induced by pairing $\beta$-adrenergic receptor activation with one train of HFS also required protein synthesis. Bath application of emetine caused L-LTP to gradually decay (Fig. 4C) (fEPSPs were 107.6 $\pm 2.6 \%$ $120 \mathrm{~min}$ after $100 \mathrm{~Hz} ; p<0.01$ compared with ISO plus $1 \times 100 \mathrm{~Hz}$ alone). Therefore, like L-LTP generated by multiple trains of HFS, protein synthesis is required for L-LTP induced by the activation of $\beta$-adrenergic receptors during stimulation that normally does not induce protein synthesis-dependent L-LTP. Previous studies have shown that the protein synthesis inhibitors used do not affect hippocampal slice viability (Stanton and Sarvey, 1984; Frey et al., 1988). Our second pathway data also show that inhibition of protein synthesis does not affect basal synaptic transmission in hippocampal slices, consistent with these previous reports (Krug et al., 1984; Frey et al., 1988; Nguyen et al., 1994; Scharf et al., 2002).

\section{Somatic transcription is not required for L-LTP induced by $\boldsymbol{\beta}$-adrenergic receptor activation paired with subthreshold stimulation}

Studies of long-term synaptic plasticity have focused on the roles of gene expression at the transcriptional level (Sossin, 1996; Martin and Kosik, 2002; Deisseroth et al., 2003). Transcription is needed for expression of some forms of L-LTP (Abraham et al., 1993; Nguyen et al., 1994; Frey et al., 1996; Nayak et al., 1998; Jones et al., 2001; Ying et al., 2002). We therefore investigated whether L-LTP initiated by pairing $\beta$-adrenergic receptor activation with LFS requires transcription. We used a transcriptional inhibitor, ACT-D, at a concentration $(25 \mu \mathrm{M})$ that has been 
shown to block transcription by $>70 \%$ in hippocampal slices (Nguyen et al., 1994). Bath application of ACT-D did not inhibit L-LTP induced by ISO paired with LFS (Fig. 5A) (fEPSPs were $157.7 \pm 12.1 \%$ at 120 min after LFS), indicating that transcription is not necessary for this form of L-LTP. L-LTP produced by pairing $\beta$-adrenergic receptor activation with one train of HFS is also independent of transcription. Application of ACT-D did not inhibit L-LTP induced by this stimulation protocol (Fig. 5B) (fEPSPs were $151.9 \pm$ $12.0 \% 120 \mathrm{~min}$ after $100 \mathrm{~Hz} ; p>0.05$ compared with ISO plus $100 \mathrm{~Hz}$ alone).

We hypothesized that dendritic protein synthesis may be critical for L-LTP generated in this manner. To test this idea, we recorded from slices containing isolated CA1 pyramidal cell dendrites that were created by applying two small cuts in the stratum radiatum, adjacent to the cell body layers of areas CA1 and CA3 (Woo and Nguyen, 2003). Slices prepared in this manner allowed fEPSPs to be recorded from isolated, "desomatized" CA1 dendrites (Frey et al., 1989; Woo and Nguyen, 2003). Although these slices exhibited smaller maximal fEPSP amplitudes (ranging from 1 to $3 \mathrm{mV}$ ) than intact slices, they were still capable of robust potentiation. When ISO was bath applied to these cut slices and paired with $5 \mathrm{~Hz}$ LFS, long-lasting potentiation was observed (Fig. 5C) (fEPSPs were $141.6 \pm 10.5 \% 120 \mathrm{~min}$ after $5 \mathrm{~Hz}$ stimulation). Therefore, intact communication from the cell body layer to the dendrites is not required for expression of L-LTP generated by pairing $\beta$-adrenergic receptor activation with LFS.

However, it is possible that cutting hippocampal slices may alter the cellular state such that ISO application increases synaptic strength in a protein synthesis-independent manner. To exclude this possibility, we applied the protein synthesis inhibitor emetine during ISO plus $5 \mathrm{~Hz}$ stimulation in cut slices. As observed in uncut slices, emetine inhibited the L-LTP in cut slices (Fig. 5D) (fEPSPs were 105.7 $\pm 7.6 \% 120$ min after $5 \mathrm{~Hz}$ stimulation). Therefore, LTP observed in the cut slice preparation is similarly dependent on protein synthesis.

ANOVA analysis followed by Tukey-Kramer post hoc analyses demonstrated no significant differences between results obtained from intact slices treated with ACT-D, cut slices with ISO and 5 $\mathrm{Hz}$ LFS, and intact slices with ISO and $5 \mathrm{~Hz}$. However, these slice treatments all were significantly different from cut slices treated with ISO, emetine, and 5 Hz. (Fig. $5 E)\left(F_{(3,26)}=5.432 ; p<0.01\right)$. When considered alongside our results of Figure 4 , these data suggest that local, dendritic translation is needed for expression of L-LTP by conjoint activation of $\beta$-adrenergic receptors and LFS.

\section{L-LTP induced by $\boldsymbol{\beta}$-adrenergic receptor activation paired with subthreshold stimulation does not exhibit a late transcriptional component}

In some slice preparations, L-LTP has been shown to last up to $8 \mathrm{~h}$ (Frey et al., 1996). This L-LTP demonstrates a dependence on
B.
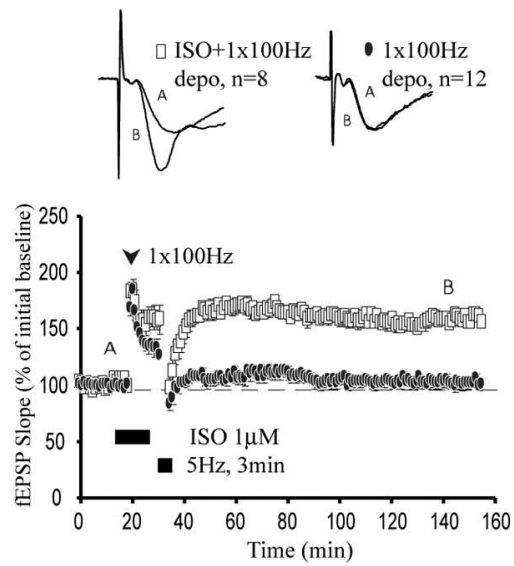

D.

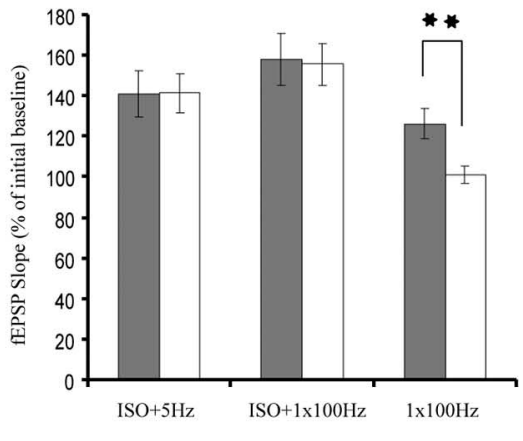

Figure 3. $\beta$-Adrenergic receptor activation paired with subthreshold stimulation renders LTP immune to DPT. $\boldsymbol{A}$, LFS given 10

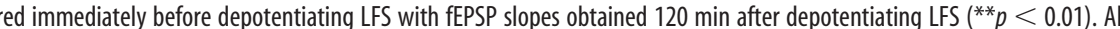
sample traces were taken $10 \mathrm{~min}$ after commencement of baseline recording and $120 \mathrm{~min}$ after depotentiating LFS stimulation. depo, Depotentiation. Calibration: $5 \mathrm{mV}, 2 \mathrm{~ms}$.

transcription that is not evident until $\sim 5 \mathrm{~h}$ after tetanus (Frey et al., 1996). In light of this data, we investigated whether our form of L-LTP is similarly long-lasting and dependent on transcription at extended time periods after induction. We observed that conjoint application of ISO and $5 \mathrm{~Hz}$ stimulation produced nondecremental LTP that was maintained for at least $6 \mathrm{~h}$ (Fig. 6 A) (fEPSPs were $149.9 \pm 16.4 \% 360 \mathrm{~min}$ after $5 \mathrm{~Hz}$ ). The duration of this form of L-LTP is therefore comparable with the duration of HFSinduced L-LTP observed in hippocampal slices. Application of ACT-D had no effect on the maintenance of L-LTP at this time point (Fig. 6 B, fEPSPs were $152.9 \pm 13.3 \% 360 \mathrm{~min}$ after $5 \mathrm{~Hz}$ ). Figure $6 C$ compares the potentiation observed between slices treated with and without ACT-D in the presence of ISO plus $5 \mathrm{~Hz}$ at various times after induction. These data show that activation of $\beta$-adrenergic receptors during LFS produces L-LTP, which is stable in the absence of substantial transcription for at least $6 \mathrm{~h}$.

Overall, our results indicate that pairing $\beta$-adrenergic receptor activation with subthreshold electrical stimulation is sufficient to induce long-lasting LTP. This form of LTP can be classified as "late phase" because of its requirement for protein synthesis, its immunity to DPT, and its nondecremental maintenance for at least $6 \mathrm{~h}$. However, this L-LTP differs from HFS- 
A.
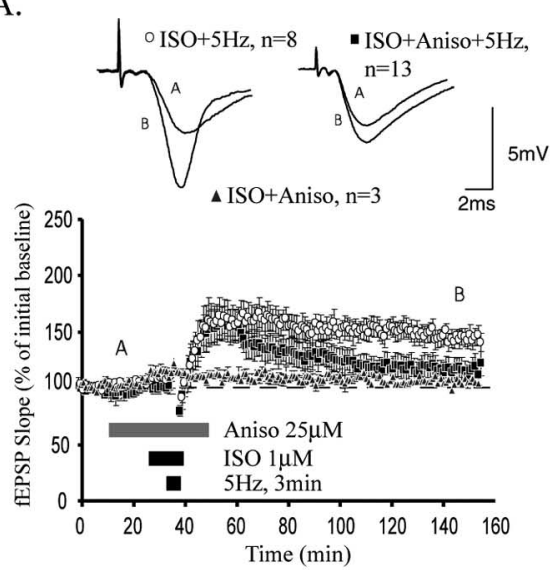

C.
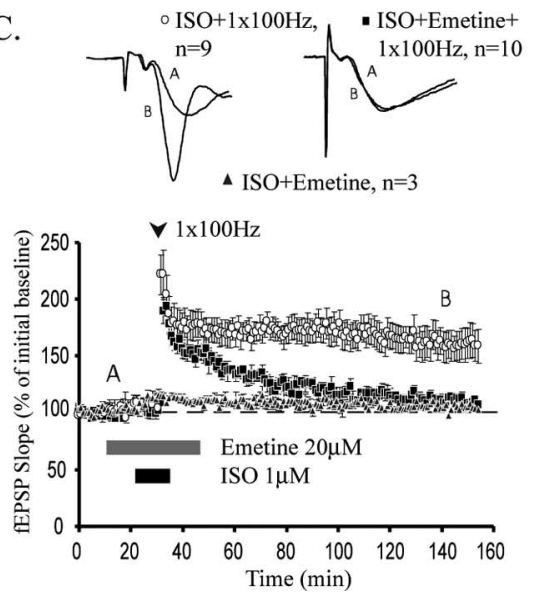

B.

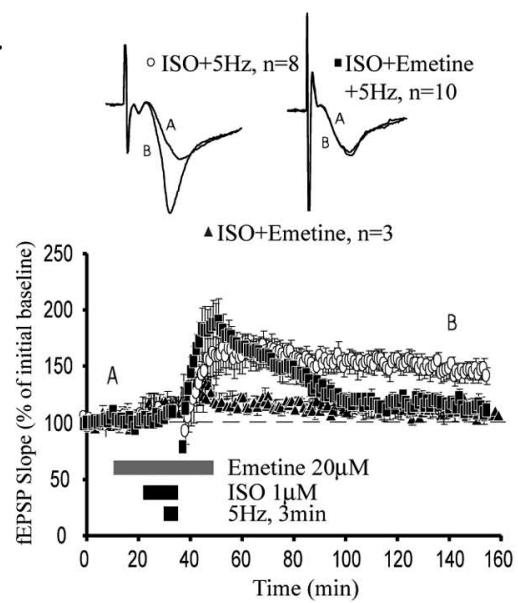

D.

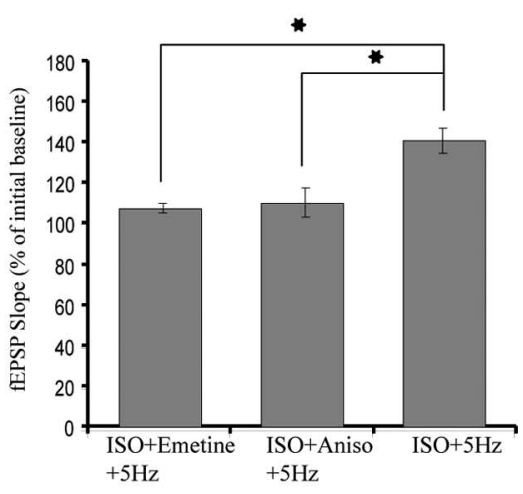

quickly and persistently to subthreshold synaptic stimulation (Thomas et al., 1996).

Conjoint activation of $\beta$-adrenergic receptors with subthreshold electrical stimulation produces LTP, which shares many properties with tetanus-induced L-LTP. This L-LTP is resistant to activity-induced reversal by depotentiating stimuli (Barco et al., 2002; Woo and Nguyen, 2002). We found that pairing $\beta$-adrenergic receptor activation with LFS induced LTP that was similarly immune to DPT. Because a critical step toward synaptic immunity to DPT is translation of mRNA (Woo and Nguyen, 2003), our results suggest that $\beta$-adrenergic receptor activation may engage intracellular pathways that regulate protein synthesis. Consistent with this hypothesis, anisomycin and emetine inhibited maintenance of $\beta$-adrenergic receptor-induced LTP.

Furthermore, transcription is not required for L-LTP induced by pairing $\beta$-adrenergic receptor activation with LFS. Intact maintenance of LTP in slices containing isolated CA1 pyramidal cell dendrites reinforces the idea that the soma is not necessary for this form of L-LTP. Dendritic translation appears to be needed to stabilize this L-LTP, because emetine selectively inhibited long-term stability of L-LTP in slices containing isolated dendrites. Multiple trains of HFS delivered to isolated dendrites in mouse hippocampal slices elicit LTP that decays shortly after tetanus (Woo and Nguyen, 2003). This decay might be caused by the inability of transcriptionally generated protein products to reach the synapse. Our results suggest that some forms of LTP may initiate maintenance and counteract decay processes using only dendritic translation products.

L-LTP, like long-term memory, is characterized mainly by its extended duration

induced L-LTP because it is independent of somatic transcription and instead requires local, dendritic protein synthesis. Our results show further that the properties of this L-LTP are generated by $\beta$-adrenergic receptor activation and depend on the downstream initiation of the MAPK cascade.

\section{Discussion}

Neuromodulatory transmitters play critical roles in regulating activity-dependent synaptic plasticity (Moody et al., 1999; Mann and Greenfield, 2003; van Dam et al., 2004). Neuromodulators such as noradrenaline can alter the sensitivity of LTP to electrical activity. Such biochemically mediated metaplasticity (cf. Abraham and Tate, 1997) can shift the plasticity induction profiles of synapses. Our results reveal that pharmacological activation of $\beta$-adrenergic receptors enhances maintenance of LTP induced by weak electrical stimulation. This facilitation appears to require dendritic protein synthesis. Activation of noradrenergic receptors may therefore enable hippocampal neurons to respond

and dependence on protein synthesis (Davis and Squire, 1984; McGaugh, 2000). $\beta$-Adrenergic receptor activation induces expression of these properties in response to electrical stimulation protocols that normally are unable to elicit long-term changes in synaptic strength. Stimulation of $\beta$-adrenergic receptors therefore appears to initiate a form of L-LTP. Tetanus-induced L-LTP also requires transcription (Nguyen et al., 1994), whereas our form of LTP is independent of transcription, even at extended time points. However, recent lines of research demonstrate that translational regulation may make important contributions to stability of long-lasting changes in synaptic efficacy (Kelleher et al., 2004b). For example, activation of metabotropic glutamate receptors in the hippocampus induces latephase long-term depression (L-LTD), which is insensitive to transcriptional inhibition (Huber et al., 2001). In agreement with our findings, this form of L-LTD reinforces the notion that translation of preexisting mRNAs can be sufficient to maintain a late phase of synaptic plasticity. 
Evidence for cellular machinery to support a specific role of dendritic translation in long-term synaptic plasticity has been found. Indeed, polyribosome complexes located in dendrites (Steward and Levy, 1982; Steward, 1983) mediate local protein synthesis in hippocampal dendrites (Steward et al., 1996). Although many of the mRNAs translated in dendrites remain uncharacterized, those that have been identified exhibit a broad range of functions, suggesting that local dendritic translation can regulate many aspects of synaptic physiology and plasticity (Steward, 1997; Bagni et al., 2000). The presence of separate somatic and dendritic pathways by which a synapse may acquire proteins crucial for L-LTP poses two intriguing questions: How do these pathways respond to different patterns of synaptic activation? How do they interact with each other?

L-LTP induced by HFS requires transcription (Abraham et al., 1993; Nguyen et al., 1994; Frey et al., 1996; Nayak et al., 1998; Jones et al., 2001; Ying et al., 2002; for review, see Steward and Schuman, 2001). Interestingly, various studies suggest a role for local protein synthesis in LTP that requires activation of neuromodulatory receptors rather than strong electrical stimulation. Application of brain-derived neurotrophic factor and neurotrophin-3 to hippocampal slices produces L-LTP that requires dendritic protein synthesis (Kang and Schuman, 1996). Also, whereas application of the muscarinic agonist carbachol, or electrical stimulation, alone does not engage de novo protein synthesis, the combination of both elicits dendritic translation (Feig and Lipton, 1993). These observations parallel our results observed when $\beta$-adrenergic receptor activation is combined with LFS. Altogether, our data suggest that L-LTP mediated by $\beta$-adrenergic receptor activation requires local protein synthesis but not somatic transcription. Multiple forms of long-lasting synaptic plasticity exist, and our findings add to a growing body of evidence that certain neuromodulators can induce a late phase of plasticity that bypasses transcriptional processes.

Plasticity processes that require translation but not transcription also exist in many invertebrate systems. Intermediate phase synaptic facilitation (ITF) in Aplysia requires new protein, but not mRNA, synthesis (Ghirardi et al., 1995; Mauelshagen et al., 1996). Similar intermediary phenomena have been observed in crayfish and Lymnaea (Beaumont et al., 2001; Sangha et al., 2003). L-LTP induced by pairing $\beta$-adrenergic receptor activation with subthreshold stimulation resembles ITF in its selective requirement of protein synthesis. Activation of neuromodulatory afferents

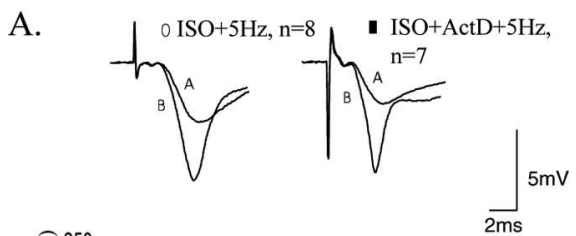

B.
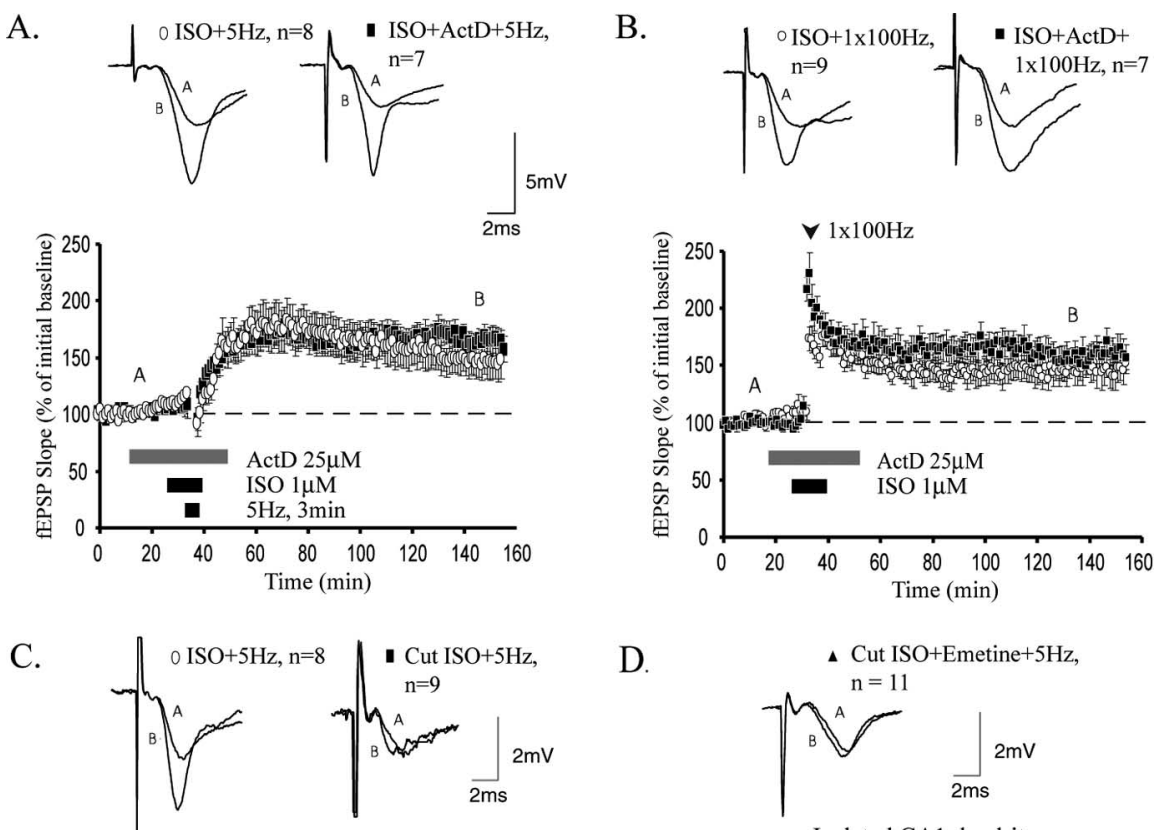

D.
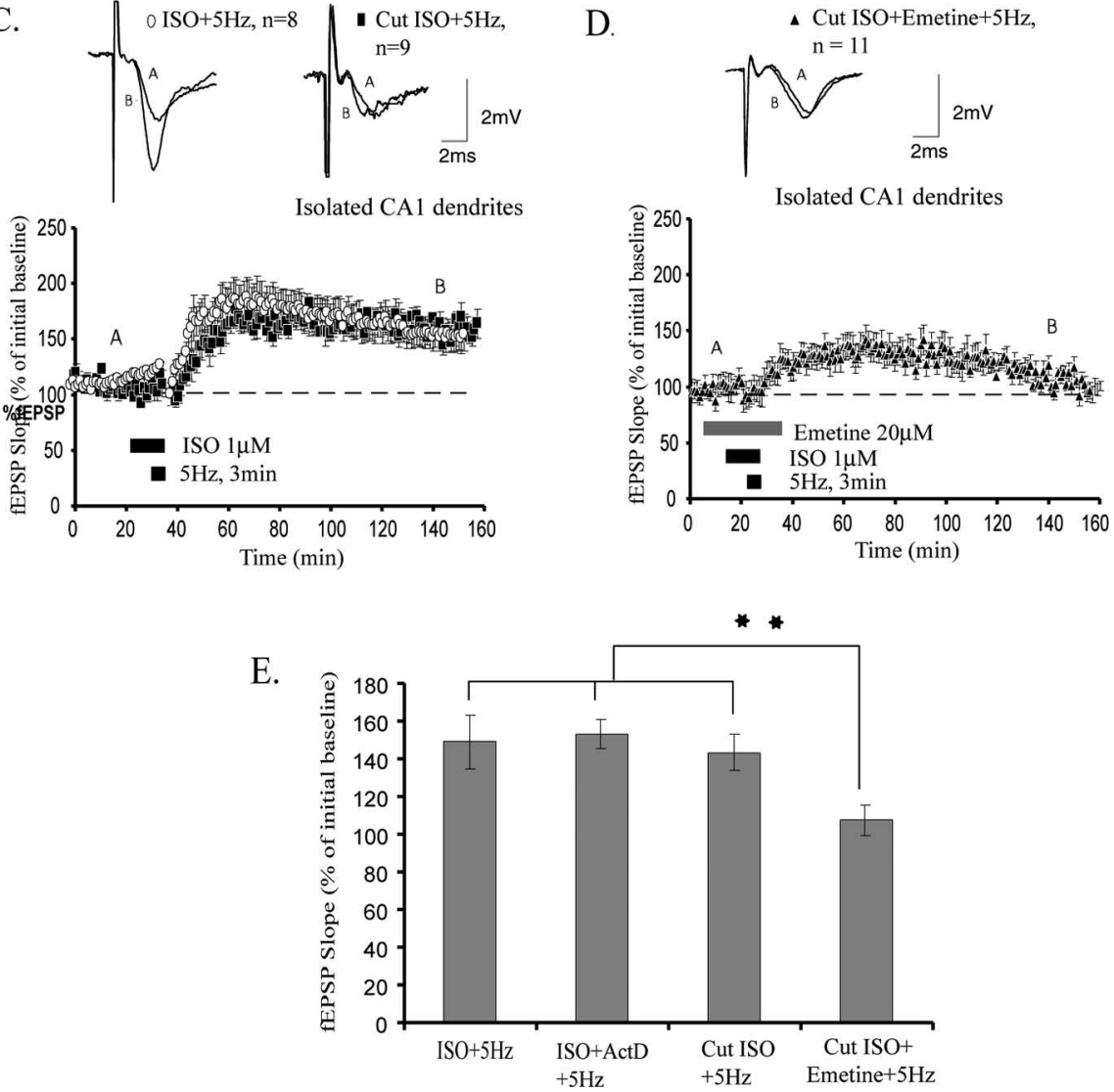

Figure 5. L-LTP induced by $\beta$-adrenergic receptor activation paired with subthreshold stimulation is independent of transcription. $\boldsymbol{A}$, Application of ACT-D did not inhibit L-LTP elicited by pairing $5 \mathrm{~Hz}$ with ISO (filled squares). B, Application of ACT-D did not inhibit L-LTP elicited by pairing $1 \times 100 \mathrm{~Hz}$ stimulation with ISO (filled squares). C, Application of ISO during $5 \mathrm{~Hz}$ generated L-LTP in isolated CA1 pyramidal cell dendrites (filled squares). $\boldsymbol{D}$, Application of emetine to cut slices treated with ISO and $5 \mathrm{~Hz}$ inhibited the maintenance of L-LTP (filled triangles). $\boldsymbol{E}$, Summary histogram comparing effects of applying ACT-D and emetine to isolated CA1 pyramidal dendrites (cut slices) ${ }^{* *} p<0.01$ ). All sample traces were taken $10 \mathrm{~min}$ after commencement of baseline recording and $120 \mathrm{~min}$ after stimulation protocol. Calibration for cut slices: $2 \mathrm{mV}, 2 \mathrm{~ms}$. Calibration for intact slices: $5 \mathrm{mV}, 2 \mathrm{~ms}$.

may therefore be a translation-dependent mechanism to selectively recruit pathways that rapidly engage long-lasting, rather than transient, changes in synaptic efficacy.

In vivo, different neuromodulators can act together to mediate cellular events. Noradrenaline and dopamine both initiate protein synthesis-dependent L-LTP in the hippocampus when paired with subthreshold stimulation (Huang and Kandel, 1995), although these effects may depend on concentrations of the ap- 
A.

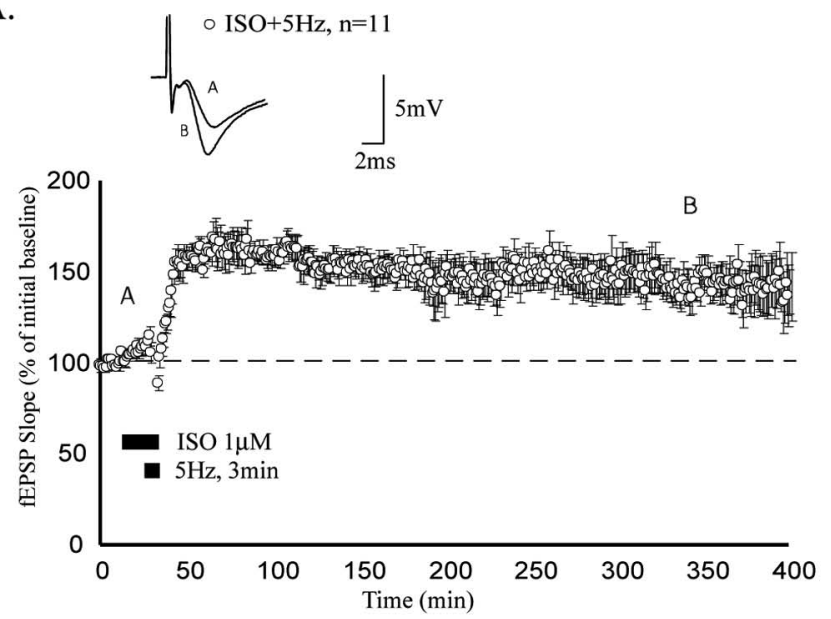

B.
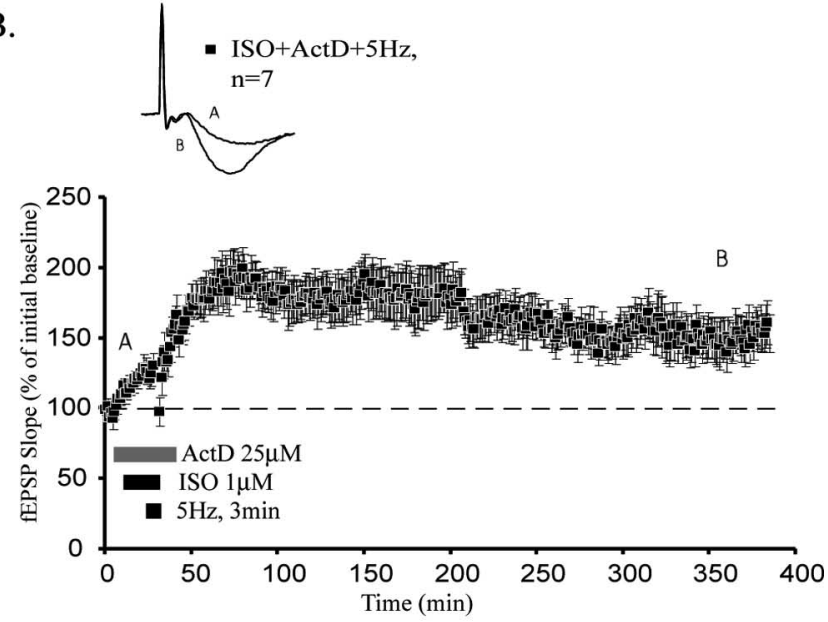

C.

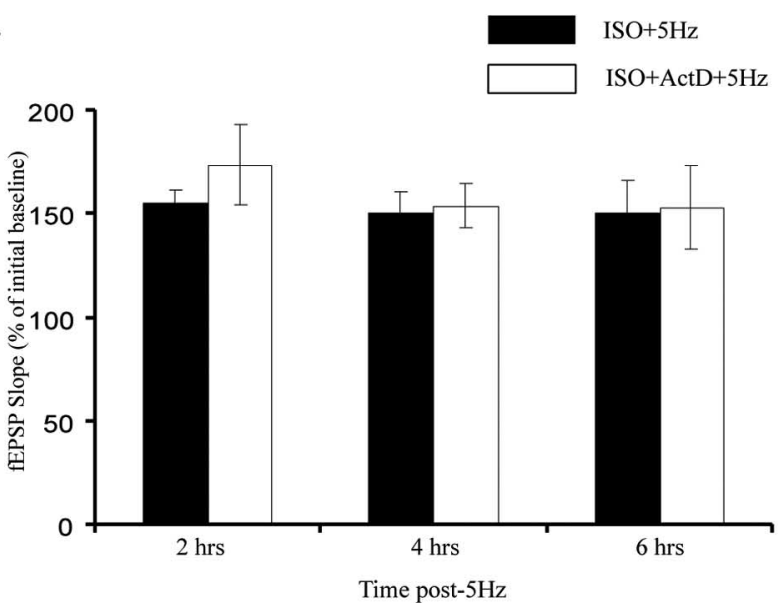

Figure 6. L-LTP induced by $\beta$-adrenergic receptor activation paired with subthreshold stimulation does not exhibit a late transcriptional component. $A$, Application of ISO during $5 \mathrm{~Hz}$ stimulation induces $\mathrm{L}$-LTP, which lasts for at least $6 \mathrm{~h}$ (open circles). $\boldsymbol{B}, \mathrm{L}$-LTP is maintained for at least $6 \mathrm{~h}$ when ACT-D is applied during ISO plus $5 \mathrm{~Hz}$ stimulation (filled squares). C, Summary histogram comparing potentiation levels of slices treated with or without ACT-D at various time points. All sample traces were taken 10 min after commencement of baseline recording and 120 min after stimulation protocol. Calibration: $5 \mathrm{mV}, 2 \mathrm{~ms}$.

plied agonist and stimulation protocols used (Swanson-Park et al., 1999). However, our data with the $\beta$-adrenergic antagonist propranolol and $\mathrm{D}_{1} / \mathrm{D}_{5}$ dopamine antagonist $\mathrm{SCH} 23390$ indicate that application of ISO induces L-LTP that is selectively de- pendent on $\beta$-adrenergic receptor activation. Genetic knock-out studies conducted by Winder et al. (1999) further suggest that this effect is mediated by $\beta 1$-adrenergic receptors only. These results raise the question of how noradrenaline and dopamine, which have similar effects on LTP, are differentially regulated.

Dopamine is required for L-LTP in area CA1 and has been linked to downstream cAMP response element-binding protein activation (Huang and Kandel, 1995; Otmakhova and Lisman, 1996; Pittenger et al., 2002). During behavior, activation of dopaminergic receptors may play a permissive role in initiating transcriptional pathways linked to L-LTP and memory. Noradrenaline is not necessary for L-LTP in CA1 (Stanton and Sarvey, 1985), and our results suggest that some of its outcomes are regulated by dendritic translation. It is possible that emotionally charged stimuli that trigger the noradrenergic system could engage translational mechanisms to enhance association and retention of stimuli that are initially subthreshold for activation of dopamine receptors.

How does $\beta$-adrenergic receptor activation link to protein synthesis and LTP maintenance? $\beta$-Adrenergic receptors have been shown to stimulate PKA via the cAMP pathway. PKA is also critical for L-LTP, and its downstream targets include transcription factors (Madison and Nicoll, 1986; Dunwiddie et al., 1992; Thomas et al., 1996; Abel et al., 1997; Brown et al., 2000). However, $\beta$-adrenergic receptors also activate the MAPK cascade (Winder et al., 1999; Giovannini et al., 2001). Our data indicate that this cascade may be selectively critical for the late phase of some forms of $\beta$-adrenergic LTP. Furthermore, recent evidence implicates MAPKs in translational control of synaptic plasticity (Kelleher et al., 2004a). This pathway may be important for signal transduction from the $\beta$-adrenergic receptor to protein synthesis and LTP maintenance. Additional mechanistic research is required to investigate this connection.

Is enhancement of L-LTP by $\beta$-adrenergic receptor activation relevant to long-term memory? Both L-LTP and long-term memory require new protein synthesis (Davis and Squire, 1984; McGaugh, 2000). Interestingly, the $\beta$-adrenergic neuromodulatory system plays a crucial role in enhancement of memory, especially during periods of heightened emotional arousal (McGaugh, 1989; Cahill et al., 1994). Recent evidence suggests that noradrenaline may be particularly important in the complex events underlying memory retrieval (Murchison et al., 2004). Regardless of specific contributions to acquisition, consolidation, or retrieval, it is clear that $\beta$-adrenergic receptor activation can importantly regulate memory processing.

Noradrenaline exerts its effects at several sites, including the amygdala and forebrain (Moore and Bloom, 1979). However, the importance of hippocampal area CA1 for rapid encoding of events that comprise "episodic memory" (Eichenbaum, 2000) indicates that hippocampal $\beta$-adrenergic receptor activation is crucial for initiating long-term memory storage and/or retrieval. Although the conclusion that L-LTP in general is a cellular mechanism for long-term memory storage remains debatable, there is strong correlative evidence to support this idea (Doyere and Laroche, 1992; Bourtchouladze et al., 1994; Abel et al., 1997; Jones et al., 2001; Genoux et al., 2002). Our results lead us to speculate that enhancement of L-LTP by pairing $\beta$-adrenergic receptor activation with LFS may contribute to noradrenergic enhancement of memory observed in previous studies (McGaugh, 1989; Cahill et al., 1994). Such enhancement of long-term memory might be initiated by synthesis of synaptically localized proteins, a process implicated in stabilization and enhancement of L-LTP (Barco et al., 2002; Kelleher et al., 2004a,b). 


\section{References}

Abel T, Nguyen PV, Barad M, Deuel TAS, Kandel ER, Bourtchouladze R (1997) Genetic demonstration of a role for PKA in the late phase of LTP and in hippocampus-based long-term memory. Cell 88:615-626.

Abraham WC, Bear MF (1996) Metaplasticity: the plasticity of synaptic plasticity. Trends Neurosci 19:126-130.

Abraham WC, Tate WP (1997) Metaplasticity: a new vista across the field of synaptic plasticity. Prog Neurobiol 52:303-323.

Abraham WC, Mason SE, Demmer J, Williams JM, Richardson CL, Tate WP, Lawlor PA, Dragunow M (1993) Correlations between immediate early gene induction and the persistence of long-term potentiation. Neuroscience 56:717-727.

Bagni C, Mannucci L, Dotti CG, Amaldi F (2000) Chemical stimulation of synaptosomes modulates $\alpha$ - $\mathrm{Ca}^{2+} /$ calmodulin-dependent protein kinase II mRNA association to polysomes. J Neurosci 20:1-6.

Barco A, Alarcon JM, Kandel ER (2002) Expression of constitutively active CREB protein facilitates the late phase of long-term potentiation by enhancing synaptic capture. Neuron 108:689-703.

Barrionuevo G, Schottler F, Lynch G (1980) The effects of repetitive low frequency stimulation on control and "potentiated" synaptic responses in the hippocampus. Life Sci 27:2385-2391.

Bashir ZI, Collingridge GL (1994) An investigation of depotentiation of long-term potentiation in the CA1 region of the hippocampus. Exp Brain Res 100:437-443.

Beaumont V, Zhong N, Fletcher R, Froemke RC, Zucker RS (2001) Phosphorylation and local presynaptic protein synthesis in calcium-andcalcineurin-dependent induction of crayfish long-term facilitation. Neuron 32:489-501.

Bliss TVP, Collingridge GL (1993) A synaptic model of memory: long-term potentiation in the hippocampus. Nature 361:31-39.

Bourtchouladze R, Frenguelli B, Blendy J, Cioffi D, Schutz G, Silva AJ (1994) Deficient long-term memory in mice with a targeted mutation of the cAMP-responsive element-binding protein. Cell 79:59-68.

Brown GP, Blitzer RD, Connor JH, Wong T, Shenolikar S, Iyengar R, Landau EM (2000) Long-term potentiation induced by theta-frequency stimulation is regulated by a protein phosphatase-1-operated gate. J Neurosci 20:7880-7887.

Brun VH, Ytterbo K, Morris RGM, Moser MB, Moser EI (2001) Retrograde amnesia for spatial memory induced by NMDA receptor-mediated LTP. J Neurosci 21:356-362.

Cahill L, Prins B, Weber M, McGaugh JL (1994) $\beta$-Adrenergic activation and memory for emotional events. Nature 371:702-704.

Dahl D, Sarvey JM (1989) Norepinephrine induces pathway-specific longlasting potentiation and depression in the hippocampal dentate gyrus. Proc Natl Acad Sci USA 86:4776-4780.

Davis HP, Squire LR (1984) Protein synthesis and memory: a review. Psychol Bull 96:518-559.

Deadwyler SA, Dunwiddie T, Lynch G (1987) A critical level of protein synthesis is required for long-term potentiation. Synapse 1:90-95.

Deisseroth K, Mermelstein PG, Xia H, Tsien RW (2003) Signaling from synapse to nucleus: the logic behind the mechanisms. Curr Opin Neurobiol 13:354-365.

Doyere V, Laroche S (1992) Linear relationship between the maintenance of hippocampal LTP and retention of an associative memory. Hippocampus 2:39-48.

Duffy SN, Craddock KJ, Abel T, Nguyen PV (2001) Environmental enrichment modifies the PKA-dependence of hippocampal LTP and improves hippocampus-dependent memory. Learn Mem 8:26-34.

Dunwiddie TV, Taylor M, Heginbotham LR, Proctor WR (1992) Longterm increases in excitability in the CAl region of rat hippocampus induced by $\beta$-adrenergic stimulation: possible mediation by cAMP. J Neurosci 12:506-517.

Eichenbaum H (2000) A cortical-hippocampal system for declarative memory. Nat Rev Neurosci 1:41-50.

Feig S, Lipton P (1993) Pairing the cholinergic agonist carbachol with patterned scaffer collateral stimulation initiates protein synthesis in hippocampal CA1 pyramidal cell dendrites via a muscarinic, NMDAdependent mechanism. J Neurosci 13:1010-1021.

Frey U, Krug M, Reymann KG, Matthies H (1988) Anisomycin, an inhibitor of protein synthesis, blocks late phases of LTP phenomena in hippocampal CA1 region in vitro. Brain Res 452:57-65.

Frey U, Krug M, Brödemann R, Reymann KG, Matthies H (1989) Long- term potentiation induced in dendrites separated from rat's CA1 pyramidal somata does not establish a late phase. Neurosci Lett 97:135-139.

Frey U, Frey S, Schollmeier F, Krug M (1996) Influence of actinomycin D, a RNA synthesis inhibitor, on long-term potentiation in rat hippocampal neurons in vivo and in vitro. J Physiol (Lond) 490:703-711.

Fujii S, Saito K, Miyakawa H, Ito K-I, Kato H (1991) Reversal of long-term potentiation (depotentiation) induced by tetanus stimulation of the input to CA1 neurons of guinea pig hippocampal slices. Brain Res 555:112-122.

Genoux D, Haditsch U, Knobloch M, Michalon A, Storm D, Mansuy IM (2002) Protein phosphatase 1 is a molecular constraint on learning and memory. Nature 418:970-975.

Ghirardi M, Montarolo PG, Kandel ER (1995) A novel intermediate stage in the transition between short-and long-term facilitation in the sensory to motor synapse of Aplysia. Neuron 14:413-420.

Giovannini MG, Blitzer RD, Wong T, Asoma K, Tsokas P, Morrison JH, Iyengar R, Landau EM (2001) Mitogen-activated protein kinase regulates early phosphorylation and delayed expression of $\mathrm{Ca}^{2+} / \mathrm{calmodulin}-$ dependent protein kinase II in long-term potentiation. J Neurosci 21:7053-7062.

Hopkins WF, Johnston D (1984) Frequency-dependent noradrenergic modulation of long-term potentiation in the hippocampus. Science 226:350-352.

Hopkins WF, Johnston D (1988) Noradrenergic enhancement of long-term potentiation at mossy fiber synapses in the hippocampus. J Neurophysiol 59:667-687.

Huang CC, Liang YC, Hsu KS (1999) A role for extracellular adenosine in time-dependent reversal of long-term potentiation by low-frequency stimulation at hippocampal CA1 synapses. J Neurosci 19:9728-9738.

Huang YY, Kandel ER (1994) Recruitment of long-lasting and protein kinase A-dependent long-term potentiation in the CA1 region of hippocampus requires repeated tetanization. Learn Mem 1:74-82.

Huang YY, Kandel ER (1995) D1/D5 receptor agonists induce a protein synthesis-dependent late potentiation in the CA1 region of the hippocampus. Proc Natl Acad Sci USA 92:2446-2450.

Huang YY, Kandel ER (1996) Modulation of both the early and the late phase of mossy fiber LTP by the activation of $\beta$-adrenergic receptors. Neuron 16:611-617.

Huang YY, Nguyen PV, Abel T, Kandel ER (1996) Long-lasting forms of synaptic potentiation in the mammalian hippocampus. Learn Mem 3:74-85.

Huber KM, Roder JC, Bear MF (2001) Chemical induction of mGlurR5and protein synthesis-dependent long-term depression in hippocampal area CA1. J Neurophysiol 86:321-325.

Johnston D, Wu SM-S (1995) Foundations of cellular neurophysiology. Cambridge, MA: MIT.

Jones MW, Errington ML, French PJ, Fine A, Bliss TVP, Garel S, Charnay P, Bozon B, Laroche S, Davis S (2001) A requirement for the IEG zif268 in the expression of late LTP and long-term memories. Nat Neurosci 4:289-296.

Kandel ER (2001) The molecular biology of memory storage: a dialogue between genes and synapses. Science 294:1030-1038.

Kang H, Schuman EM (1996) A requirement for local protein synthesis in neurotrophin-induced hippocampal synaptic plasticity. Science 73:1402-1406.

Katsuki H, Izumi Y, Zorumski CF (1997) Noradrenergic regulation of synaptic plasticity in the hippocampal CA1 region. J Neurophysiol 77:3013-3020.

Kelleher III RJ, Govindarajan A, Jung HY, Kang H, Tonegawa S (2004a) Translational control by MAPK signalling in long-term synaptic plasticity and memory. Cell 116:467-479.

Kelleher III RJ, Govindarajan A, Tonegawa S (2004b) Translational regulatory mechanisms in persistent forms of synaptic plasticity. Neuron 44:59-73.

Krug M, Loessner B, Ott T (1984) Anisomycin blocks the late phase of LTP in the dentate gyrus of freely moving rats. Brain Res Bull 13:39-42.

Loy R, Koziell DA, Lindsey JD, Moore RY (1980) Noradrenergic innervation of the adult rat hippocampal formation. J Comp Neurol 189:699-710.

Madison DV, Nicoll R (1986) Actions of noradrenaline recorded intracellularly in rat hippocampal CA1 pyramidal neurones, in vitro. J Physiol Lond 372:221-244.

Mann EO, Greenfield SA (2003) Novel modulatory mechanisms revealed by 
the sustained application of nicotine in the guinea pig hippocampus in vitro. J Physiol (Lond) 551:539-550.

Martin KC, Kosik KS (2002) Synaptic tagging — who's it? Nat Rev Neurosci 3:813-820.

Martin S, Grimwood P, Morris RGM (2000) Synaptic plasticity and memory: an evaluation of the hypothesis. Annu Rev Neurosci 23:649-711.

Mauelshagen J, Parker GR, Carew TJ (1996) Dynamics of induction and expression of long-term synaptic facilitation in Aplysia. J Neurosci 16:7099-7108.

McGaugh JL (1989) Involvement of hormonal and neuromodulatory systems in the regulation of memory storage. Annu Rev Neurosci 12:255-287.

McGaugh JL (2000) Memory-a century of consolidation. Science 287:248-251

Moody TD, Carlisle HJ, O’Dell TJ (1999) A nitric oxide-independent and $\beta$-adrenergic receptor-sensitive form of metaplasticity limts thetafrequency stimulation-induced LTP in the hippocampal CA1 region. Learn Mem 6:619-633.

Moore RY, Bloom FE (1979) Central catecholamine neuron systems: anatomy and physiology of the norepinephrine and epinephrine systems. Annu Rev Neurosci 2:113-168.

Moser EI, Krobert KA, Moser MB, Morris RGM (1998) Impaired spatial learning after saturation of long-term potentiation. Science 281:2038-2042.

Murchison CF, Zhang XY, Zhang WP, Ouyang M, Lee A, Thomas SA (2004) A distinct role for norepinephrine in memory retrieval. Cell 117:131-143.

Nathe AR, Frank LM (2003) Making space for rats: from synapse to place code. Neuron 39:730-731.

Nayak A, Zastrow DJ, Lickteig R, Zahniser NR, Browning MD (1998) Maintenance of late-phase LTP is accompanied by PKA-dependent increase in AMPA receptor synthesis. Nature 394:680-683.

Nguyen PV, Kandel ER (1996) A macromolecular synthesis-dependent late phase of long-term potentiation requiring cAMP in the medial perforant pathway of rat hippocampal slices. J Neurosci 16:3189-3198.

Nguyen PV, Kandel ER (1997) Brief theta-burst stimulation induces a transcription-dependent late phase of LTP requiring cAMP in area CA1 of the mouse hippocampus. Learn Mem 4:230-243.

Nguyen PV, Abel T, Kandel ER (1994) Requirement of a critical period of transcription for induction of late phase of LTP. Science 265:1104-1107.

O'Dell TJ, Kandel ER (1994) Low-frequency stimulation erases LTP through an NMDA receptor-mediated activation of protein phosphatases. Learn Mem 1:129-139.

Otmakhova NA, Lisman JE (1996) $\mathrm{D}_{1} / \mathrm{D}_{5}$ dopamine receptor activation increases the magnitude of early long-term potentiation at CA1 hippocampal synapses. J Neurosci 16:7478-7486.

Pittenger C, Huang YY, Paletzki RF, Bourtchouladze R, Scanlin H, Vronshaya S, Kandel ER (2002) Reversible inhibition of CREB/ATF transcription factors in region CA1 of the dorsal hippocampus disrupts hippocampusdependent spatial memory. Neuron 34:447-462.

Raman IM, Tong G, Jahr CE (1996) $\beta$-Adrenergic regulation of synaptic NMDA receptors by c-AMP-dependent protein kinase. Neuron 16:415-421.

Sangha S, Scheibenstock A, McComb C, Lukowiak K (2003) Intermediate and long-term memories of associative learning are differentially affected by transcription versus translation blockers in Lymnaea. J Exp Biol 206:1605-1613.

Scharf MT, Woo NH, Lattal KM, Young JZ, Nguyen PV, Abel T (2002) Protein synthesis is required for the enhancement of long-term potenti- ation and long-term memory by spaced training. J Neurophysiol 87:2770-2777.

Schimanski LA, Wahlsten D, Nguyen PV (2002) Selective modification of short-term hippocampal synaptic plasticity and impaired memory extinction in mice with a congenitally reduced hippocampal commissure. J Neurosci 22:8277-8286.

Segal M (1982) Norepinephrine modulates reactivity of hippocampal cells to chemical stimulation in vitro. Exp Neurol 77:86-93.

Sossin WS (1996) Mechanisms for the generation of synapse specificity in long-term memory: the implications of a requirement for transcription. Trends Neurosci 19:215-218.

Stanton PK, Sarvey JM (1984) Blockade of long-term potentiation in rat hippocampal slices by inhibitors of protein synthesis. J Neurosci 4:3080-3088.

Stanton PK, Sarvey JM (1985) Depletion of norepinephrine, but not serotonin, reduces long-term potentiation in the dentate gyrus of rat hippocampal slices. J Neurosci 5:2169-2176.

Staubli U, Lynch G (1990) Stable depression of potentiated synaptic responses in hippocampus with $1-5 \mathrm{~Hz}$ stimulation. Brain Res 513:113-118.

Steward O (1983) Polyribosomes at the base of dendritic spines of CNS neurons: their possible role in synapse construction and modification. Cold Spring Harbor Symp Quant Biol 48:745-759.

Steward O (1997) mRNA localization in neurons: a multipurpose mechanism. Neuron 18:9-12.

Steward O, Levy WB (1982) Preferential localization of polyribosomes under the base of dendritic spines in granule cells of the dentate gyrus. J Neurosci 2:284-291.

Steward O, Schuman EM (2001) Protein synthesis at synaptic sites on dendrites. Annu Rev Neurosci 24:299-325.

Steward O, Falk PM, Torre ER (1996) Ultrastructural basis for gene expression at the synapse: synapse-associated polyribosome complexes. J Neurocytol 25:717-734.

Swanson-Park JL, Coussens CM, Mason-Parker SE, Raymond CR, Hargreaves EL, Dragunow M, Cohen AS, Abraham WC (1999) A double dissociation within the hippocampus of dopamine D1/D5 receptor and $\beta$-adrenergic receptor contributions to the persistence of long-term potentiation. Neuroscience 92:485-497.

Thomas MJ, Moody TD, Makhinson M, O'Dell TJ (1996) Activitydependent $\beta$-adrenergic modulation of low frequency stimulation induced LTP in the hippocampal CA1 region. Neuron 17:475-482.

van Dam EJ, Kamal A, Artola A, de Graan PN, Gispen WH, Ramakers GM (2004) Group 1 metabotropic glutamate receptors regulate the frequency-response function of hippocampal CA1 synapses for the induction of LTP and LTD. Eur J Neurosci 19:112-118.

Winder DG, Martin KC, Muzzio IA, Rohrer D, Chruscinski A, Kobilka B, Kandel ER (1999) ERK plays a regulatory role in induction of LTP by theta frequency stimulation and its modulation by $\beta$-adrenergic receptors. Neuron 24:715-726.

Woo NH, Nguyen PV (2002) "Silent" metaplasticity of the late phase of LTP requires protein phosphatases. Learn Mem 9:202-213.

Woo NH, Nguyen PV (2003) Protein synthesis is required for synaptic immunity to depotentiation. J Neurosci 23:1125-1132.

Ying SW, Futter M, Rosenblum K, Webber MJ, Hunt SP, Bliss TVP, Bramham CR (2002) BDNF induces LTP in intact adult hippocampus: requirement for ERK activation coupled to CREB and upregulation of Arc synthesis. J Neurosci 22:1532-1540. 